\title{
Effective use of JC virus PCR for diagnosis of progressive multifocal leukoencephalopathy
}

\author{
Yihong Wang, James E. Kirby and Oinfang Qian \\ Department of Pathology, Beth Israel Deaconess Medical Center and Harvard Medical School, \\ Boston, MA 02215, USA
}

Correspondence

Qinfang Qian

qqian@bidmc.harvard.edu

Received 11 July 2008

Accepted 5 October 2008

\begin{abstract}
In a retrospective review of data from 168 patients with suspected progressive multifocal leukoencephalopathy (PML) between 1996 and 2006, JC virus (JCV) PCR on cerebrospinal fluid (CSF) samples was positive only in human immunodeficiency virus (HIV)-infected patients with low CD4 cell counts and in severely immunocompromised patients with radiographic lesions consistent with PML or infectious processes generally. Of note, one HIV patient with a very low CD4 cell count had a positive JCV PCR despite a normal magnetic resonance imaging exam. We concluded that JCV PCR testing on CSF specimens should therefore be targeted to these high-risk patients.
\end{abstract}

\section{INTRODUCTION}

Progressive multifocal leukoencephalopathy (PML) is a demyelinating disease of the central nervous system resulting from reactivation of JC virus (JCV) in immunocompromised patients (Martínez et al., 1995). The diagnosis of PML is generally suggested by multifocal white matter abnormalities observed by magnetic resonance imaging (MRI) (Cinque et al., 1996). In addition, JCV PCR testing of cerebrospinal fluid (CSF) allows direct and definitive laboratory confirmation of PML by detecting reactivated virus. However, as yet, algorithms for the cost effective use of this expensive and labour-intensive test have not been well defined. A previous study found that limiting herpes simplex virus PCR testing in the CSF to patients with elevated CSF leukocytes and/or protein would save money without reducing sensitivity (Tang et al., 1999). Therefore, we retrospectively analysed whether pre-existing laboratory and clinical data might similarly preclude PML, and thereby allow more selective use of JCV PCR testing.

\section{METHODS}

We retrospectively evaluated patients who had a JCV PCR test done on their CSF samples between 1996 and 2006 in our urban, tertiarycare medical centre. A total of 177 CSF specimens were obtained from these 168 patients, including 127 (75.6\%) HIV-positive, 20 (11.9\%) HIV-negative-immunocompromised and 21 (12.5\%) HIV-negativeimmunocompetent patients. All CSF samples were sent to the Mayo Clinic (Rochester, MN, USA) for JCV PCR-Southern hybridization testing. The sensitivity of this JCV PCR assay was determined to be 110 genome equivalents per reaction $\left[25-250\right.$ copies $\left.(\mathrm{ml} \mathrm{sample})^{-1}\right]$ (in-house Mayo Clinic procedure manual; Ryschkewitsch et al., 2004). All other tests were performed at our clinical laboratory.

Abbreviations: CSF, cerebrospinal fluid; HAART, highly active antiretroviral therapy; JCV, JC virus; MRI, magnetic resonance imaging; $\mathrm{PML}$, progressive multifocal leukoencephalopathy.
Standard methods were used for cell counts and protein measurement. HIV RNA levels were measured by COBAS AMPLICOR HIV-1 monitor quantitative PCR (version 1.5; Roche Diagnostics) according to the manufacturer's instructions (Murphy et al., 2000). The lower and upper limits of quantification of the HIV assay were 50 and 1000000 copies $\mathrm{ml}^{-1}$, respectively. Statistical analyses were performed by GraphPad Prism 4 software (version 4.03, 2005).

\section{RESULTS AND DISCUSSION}

A total of 18 specimens from 18 patients were positive by JCV PCR, 17 from HIV-positive patients and 1 from an HIV-negative patient with lymphoma. Our data are consistent with previous observations of the rarity of PML in HIV-negative patients (Berger et al., 1998). However, surprisingly, JCV PCR was positive in only $24 \%$ of patients with radiology findings suggestive of PML (Table 1). This low detection rate may be due to non-specificity of radiological findings (Antinori et al., 1997) or insensitivity of PCR, or perhaps due to highly active antiretroviral therapy (HAART) re-establishing host immune function and reducing JCV below detectable levels (Koralnik, 2006). These possibilities are supported by the findings that PML is often difficult to distinguish radiographically from lesions caused by HIV encephalopathy (Olsen et al., 1988; Koralnik et al., 1999) and that the sensitivity of JCV PCR dropped from $89.5 \%$ in the pre-HAART era (1992-1995) to $57.5 \%$ in the HAART era (1996-2002) (Marzocchetti et al., 2005). Interestingly, JCV PCR was also positive in $19 \%$ of patients with abnormal white matter radiology findings suggestive of infection but not characteristic of PML. In contrast, JCV PCR was negative $(0 / 48)$ in patients with non-infectious findings, such as trauma, vascular lesions, haematoma or old resolving lesions known from nonPML diseases (Table 1). 
Table 1. Correlation of JCV PCR positivity with MRI radiology findings

\begin{tabular}{|cccc|}
\hline \multicolumn{4}{|c|}{$\begin{array}{c}\text { No. of JCV-positive patients (\%) in each radiology image } \\
\text { category: }\end{array}$} \\
\hline $\mathrm{PML}^{\star}(\boldsymbol{n}=37)$ & $\mathrm{I} \dagger(\boldsymbol{n}=\mathbf{4 3})$ & $\mathrm{NI}(\boldsymbol{n}=\mathbf{4 8})$ & $\mathrm{N} \S(\boldsymbol{n}=\mathbf{4 0 )}$ \\
\hline $9(24)$ & $8(19)$ & $0(0)$ & $1(2.5)$ \\
\hline
\end{tabular}

*Abnormal image suggestive of PML.

$\dagger$ Abnormal image suggestive of infectious aetiology.

$\ddagger$ Abnormal image suggestive of non-infectious cause.

$\S$ Normal image.

Although multifocal white matter lesions are the hallmark radiographic abnormality in PML, the potential for PML in the absence of radiological findings has not been well defined. We found that 17/18 JCV-positive patients had abnormal MRI findings in the white matter suggestive of PML or an infectious process more generally. A single patient with a positive JCV PCR had normal MRI findings. This patient presented with typical clinical manifestations of PML including rapid progress of lower extremity weakness, blurry vision and occasional double vision, and ataxia. Clinically, the patient had advanced AIDS with an HIV viral load of 19739 copies $\mathrm{ml}^{-1}$, a CD4 cell count of 12 cells $\mu^{-1}$ and slightly elevated CSF protein $(65 \mathrm{mg}$ $\mathrm{dl}^{-1}$ ). However, the presumptive diagnosis of PML could not be confirmed in the absence of histological examination to resolve the discrepancy between benign radiographic features and severe clinical disease. Of note, there was a report of a similarly symptomatic HIV-positive patient with a positive JCV PCR and absence of radiographic lesions aside from slight cerebral atrophy (Di Giambenedetto et al., 2004), suggesting the potential for PML in the absence of detectable radiographic findings in HIV-positive patients.

As observed by Berger et al. (1987), JCV infection did not elicit an extensive inflammatory response in CSF (Table 2). Among JCV-positive specimens analysed for CSF white blood cell count and/or protein levels, $71 \%(12 / 17)$ had normal cell counts $\left(0-5 \mu \mathrm{l}^{-1}\right)$ and protein levels (15$\left.45 \mathrm{mg} \mathrm{dl}{ }^{-1}\right), 29 \%(5 / 17)$ had slightly elevated protein levels $\left(46-80 \mathrm{mg} \mathrm{dl}^{-1}\right)$, and $6 \%(1 / 18)$ had a slightly elevated leukocyte count ( 16 cells $\mu \mathrm{l}^{-1}$ ). Therefore, high protein levels $\left(>80 \mathrm{mg} \mathrm{dl}^{-1}\right)$ and/or high leukocyte count $\left(>20\right.$ cells $\left.\mu \mathrm{l}^{-1}\right)$ in CSF may suggest an alternative cause of central nervous system abnormalities rather than PML.

In contrast, JCV PCR positivity correlated highly with low CD4 cell counts (normal range 350-1100 cells $\mu \mathrm{l}^{-1}$ ) in HIV-positive samples. The mean CD4 cell counts were significantly lower for the 17 JCV PCR-positive samples (98 cells $\mu \mathrm{l}^{-1}$, range 5-258 cell $\mu \mathrm{l}^{-1}$ ) than for the 47 JCV PCRnegative samples $\left(171\right.$ cells $\mu \mathrm{l}^{-1}$, range $0-1135$ cell $_{\mu \mathrm{l}^{-1}}$ ), where contemporaneous $\mathrm{CD} 4$ cell counts were available ( $P=0.029$, one-tailed Student's $t$-test). Of the JCV PCRpositive samples, $65 \%(11 / 17)$ had $<100$ cells $_{\mu l}^{-1}$ and $94 \%(16 / 17)$ had $<250$ cells $\mu \mathrm{l}^{-1}$. In contrast, in the preHAART era, it was reported that only $33 \%(4 / 12)$ HIV patients with PML had a CD4 count $<100$ cells $\mu^{-1}$, although all patients had below normal CD4 counts (Miralles et al., 1998). Therefore, our results suggest that in the HAART era, JCV positivity tends to occur in patients with lower CD4 cell counts, and not necessarily PML itself.

Unexpectedly, HIV plasma viral load did not correlate with JCV PCR positivity. Only $35 \%$ (6/17) of JCV PCR-positive patients had highly elevated HIV viral loads $>10000$ copies $\mathrm{ml}^{-1}$. Furthermore, $18 \%(3 / 17)$ had HIV viral loads of 1000-10 000 copies $\mathrm{ml}^{-1} ; 24 \%(4 / 17)$ had HIV viral loads of 50-1000 copies $\mathrm{ml}^{-1}$; and $24 \%(4 / 17)$ had undetectable HIV viral loads $\left(<50\right.$ copies $\left.\mathrm{ml}^{-1}\right)$. All four patients with undetectable viral loads had elevated viral loads during the 6 months prior to the positive JCV result, three with $>10000$ copies $\mathrm{ml}^{-1}$ and one with $>1000$ copies $\mathrm{ml}^{-1}$ suggesting historical suboptimal control of infection. Our results suggest that control of HIV infection did not appear to prevent PML in the later stage of AIDS.

We conclude that JCV PCR of CSF samples should not be carried out for (a) HIV patients with normal CD4 cell counts, (b) immunocompetent patients, and (c) patients with normal radiology or findings consistent with noninfectious processes unless it is clinically highly indicated. Furthermore, low HIV viral load or normal CSF values should not be used to exclude the disease. Targeted testing based on these criteria will preserve limiting amounts of CSF for detection of more likely aetiologies and decrease costs by avoiding unnecessary JCV PCR testing.

Table 2. Correlation of JCV positivity with CSF protein and leukocyte count

\begin{tabular}{|c|c|c|c|c|c|}
\hline \multicolumn{6}{|c|}{ No. of JCV-positive patients (\%) } \\
\hline \multicolumn{3}{|c|}{ Protein $\left(\mathrm{mg} \mathrm{dl}^{-1}\right)$} & \multicolumn{3}{|c|}{ Leukocyte (cells $\mu \mathrm{l}^{-1}$ ) } \\
\hline $\begin{array}{c}15-45 \begin{array}{c}(\text { normal range }) \\
\left(n^{*}=89\right)\end{array}\end{array}$ & $46-80\left(n^{\star}=56\right)$ & $>80\left(n^{*}=29\right)$ & $\begin{array}{c}0-5 \text { (normal range) } \\
\left(n^{\star}=136\right)\end{array}$ & $6-20\left(n^{\star}=24\right)$ & $>20\left(n^{\star}=15\right)$ \\
\hline $12(14)$ & $5(9)$ & $0(0)$ & $17(13)$ & $1(4)$ & $0(0)$ \\
\hline
\end{tabular}

${ }^{\star}$ Number of CSF samples tested. 


\section{REFERENCES}

Antinori, A., Ammassari, A., De Luca, A., Cingolani, A., Murri, R., Scoppettuolo, G., Fortini, M., Tartaglione, T., Larocca, L. M. \& other authors (1997). Diagnosis of AIDS-related focal brain lesions: a decision-making analysis based on clinical and neuroradiologic characteristics combined with polymerase chain reaction assays in CSF. Neurology 48, 687-694.

Berger, J. R., Kaszovitz, B., Post, M. J. \& Dickinson, G. (1987). Progressive multifocal leukoencephalopathy associated with human immunodeficiency virus infection. A review of the literature with a report of sixteen cases. Ann Intern Med 107, 78-87.

Berger, J. R., Pall, L., Lanska, D. \& Whiteman, M. (1998). Progressive multifocal leukoencephalopathy in patients with HIV infection. $J$ Neurovirol 4, 59-68.

Cinque, P., Vago, L., Dahl, H., Brytting, M., Terreni, M. R., Fornara, C., Racca, S., Castagna, A., Monforte, A. D. \& other authors (1996). Polymerase chain reaction on cerebrospinal fluid for diagnosis of virus-associated opportunistic diseases of the central nervous system in HIV-infected patients. AIDS 10, 951-958.

Di Giambenedetto, S., Vago, G., Pompucci, A., Scoppettuolo, G., Cingolani, A., Marzocchetti, A., Tumbarello, M., Cauda, R. \& De Luca, A. (2004). Fatal inflammatory AIDS-associated PML with high CD4 counts on HAART: a new clinical entity? Neurology 63, 2452-2453.

Koralnik, I. J. (2006). Progressive multifocal leukoencephalopathy revisited: has the disease outgrown its name? Ann Neurol 60, 162-173.

Koralnik, I. J., Boden, D., Mai, V. X., Lord, C. L. \& Letvin, N. L. (1999). JC virus DNA load in patients with and without progressive multifocal leukoencephalopathy. Neurology 52, 253-260.

Martínez, A. J., Sell, M., Mitrovics, T., Stoltenburg-Didinger, G., Iglesias-Rozas, J. R., Giraldo-Velásquez, M. A., Gosztonyi, G.,
Schneider, V. \& Cervós-Navarro, J. (1995). The neuropathology and epidemiology of AIDS. A Berlin experience. A review of 200 cases. Pathol Res Pract 191, 427-443.

Marzocchetti, A., Di Giambenedetto, S., Cingolani, A., Ammassari, A., Cauda, R. \& De Luca, A. (2005). Reduced rate of diagnostic positive detection of JC virus DNA in cerebrospinal fluid in cases of suspected progressive multifocal leukoencephalopathy in the era of potent antiretroviral therapy. J Clin Microbiol 43, 4175-4177.

Miralles, P., Berenguer, J., García de Viedma, D., Padilla, B., Cosin, J., López-Bernaldo de Quirós, J. C., Muñoz, L., Moreno, S. \& Bouza, E. (1998). Treatment of AIDS-associated progressive multifocal leukoencephalopathy with highly active antiretroviral therapy. AIDS 12, 2467-2472.

Murphy, D. G., Côte, L., Fauvel, M., René, P. \& Vincelette, J. (2000). Multicenter comparison of Roche COBAS AMPLICOR MONITOR version 1.5, Organon Teknika NucliSens QT with Extractor, and Bayer Quantiplex version 3.0 for quantification of human immunodeficiency virus type 1 RNA in plasma. J Clin Microbiol 38, 40344041.

Olsen, W. L., Longo, F. M., Mills, C. M. \& Norman, D. (1988). White matter disease in AIDS: findings at MR imaging. Radiology 169, 445448.

Ryschkewitsch, C., Jensen, P., Hou, J., Gahle, G., Fischer, S. \& Major, E. O. (2004). Comparison of PCR-Southern hybridization and quantitative real-time PCR for the detection of JC and BK viral nucleotide sequences in urine and cerebrospinal fluid. J Virol Methods 121, 217-221.

Tang, Y. W., Jr, Hibbs, K., Tau, R., Qian, Q., Skarhus, H. A., Amith, T. F. \& Persing, D. H. (1999). Effective use of polymerase chain reaction for diagnosis of central nervous system infections. Clin Infect Dis 29, 803806. 